\section{PMQR determinants among clinical isolates of ESBL and Amp C producing Serratia marcescens in Mansoura University Hospitals: A 6-year study}

\section{Abstract}

Background: Plasmid mediated quinolone resistant determinants (PMQRs) are found to be of clinical relevance because it causes decreased susceptibility to quinolones which are valuable antibiotics against intrinsically resistant Serratia marcescens. This study aimed to determine the occurrence of PMQR determinants ( $q n r$, aac $\left(6^{\prime}\right)-I b$ $\mathrm{cr}$ and qep) and their relation with extended-spectrum $\beta$-lactamase (ESBL) and / or Amp C- producing S. marcescens.

Material and Method: One hundred and eleven S. marcescens were tested for resistance to five quinolones by disc diffusion method. Testing for $q n r$, aac $\left(6^{\prime}\right)-I b-c r$ and qep was carried out by multiplex PCR, while ESBL and Amp C production were evaluated by double disc synergy test and cefoxitin Hodge test, respectively.

Results: A total of $51 / 111$ (45.9\%) S. marcescens were resistant to one or more of the tested quinolones. Among $S$. marcescens isolates, $13(11.7 \%)$ were ESBL producers and 5 (4.5\%) were Amp C producers. Multiplex PCR confirmed the presence of PMQR determinant in $14(12.6 \%)$ of $S$. marcescens isolates and these were positive for qnrA and $q n r B$ in 3 and 10 of the isolates, respectively, whereas one isolate co- harbored aac $\left(6^{\prime}\right)-I b-c r$ and qnrA. Among 13 ESBL producers, 3 and 5 isolates were positive for qnrA and $q$ nr $B$, respectively (8/13; $61.5 \%)$, whereas one isolate which has co-expressed aac $\left(6^{\prime}\right)-1 / b-c r$ and qnrA was associated with Amp C production (1/5;20\%).
Enas Hammad', Randah Helal ${ }^{2}$

1 Medical Microbiology and Immunology Department.

2 Public health and Community Medicine, Faculty of Medicine, Mansoura University, Mansoura, Egypt

Corresponding author:

Enas Hammad, MD

Đenashammad@yahoo.com 
Conclusion: This study indicated that PMQRS play significant role in the occurrence and expansion of fluoroquinolone resistance in S. macrscens. They are also associated with ESBL and Amp C producers and important cause of infections in hospitalized patients.

Key words: PMQR, ESBL, Amp C, Serratia marcescens. Egypt

Received 1-11-2015; Accepted 10-12-2015

\section{Introduction}

Serratia marcescens was considered in the past to be a harmless and non-pathogenic organism in humans, it is now becoming an important cause of hospital-associated infections including urinary tract infections, respiratory tract infections, septicemia, wound infections and meningitis [1].

Quinolones are powerful antibacterial agents against a wide range of bacteria species causing clinical infections [2]. They are particularly valuable against infections caused by Gram-negative bacteria species such as $S$. marcescens which is intractable to other antibiotics because of its intrinsic resistance [1].

Plasmid-mediates quinolone resistance (PMQR) involves three families, $q n r A, q n r B$, and $q n r s$ [3]. The presence of these enzymes is of great importance because they are not merely able to confer resistance against most available quinolones but as well are often related to extended-spectrum $\beta$-lactamases (ESBLs) and/or plasmid-mediated Amp C $\beta$-lactamases (pAmp Cs) [4]. Six determinants of QnrA has been recorded worldwide from different enterobacterial species. This gene codes for a 218 amino acid protein of the pentapeptide family that prevent binding of quinolone to gyrase and topoisomerase IV protecting DNA [5]. Two other PMQR genes, called, qnrB and qnrS, have been recognized that code for QnrB and QnrS and share $41 \%$ and $60 \%$ amino acid homology with QnrA, respectively [6].
Another mechanism of conjugal quinolone resistance via an enzymatic inactivation of some quinolones by means of aminoglycoside acetyltransferase that codes for $\mathrm{cr}$ variant of $\operatorname{aac}\left(6^{\prime}\right)$ Ib was detected. It acts by $\mathrm{N}$-acetylation of their piperazinyl amine causing decreased susceptibility to quinolone. They have the same mechanism of action like QnrA [7].

Lastly, the extra PMQR determinants is the quinolone efflux pump gene, qepA. It shared a substantial resemblance to the major facilitator superfamily-type efflux pumps. This protein cause reduced susceptibility to many quinolones [8].

This study was conducted to find out the rate of PMQR determinants ( $q n r$, aac $\left(6^{\prime}\right)-l b-c r$ and qep) in S. marcescens isolated from hospitalized patients at the Mansoura University Hospitals and their association with extended-spectrum $\beta$-lactamase (ESBL) and / or Amp C- producing S. marcescens.

\section{Material and methods}

\section{Study design}

This prospective study was carried out over a period of 6 years from January 2008 through January 2014, where S. marcescens strains were isolated from various clinical samples obtained from patients at the Mansoura University Hospitals (MUHs), Mansoura, Egypt. The samples processing were carried out in diagnostics and infection control unit (MDICU). 
All samples were cultured on Blood and MacConkey's agar. Identification of S. marcescens isolates to species level was done primarily by Gram stain, colonial morphology, biochemical reactions including indole, methyl red, voges proskauer and citrate test (IMVC), motility on semisolid agar, DNAase, gelatin liquefaction tests and confirmed later with API 20E (bioMérieux) [9].

All isolates were tested for antibiotic susceptibility by disc diffusion method according to CLSI guidelines [10]. The isolates were tested against amoxicillin/ clavulanic acid $(20 / 10 \mu \mathrm{g})$, ceftazidime $(30 \mu \mathrm{g})$, cefepime $(30 \mu \mathrm{g})$, imipenem $(10 \mu \mathrm{g})$, gentamicin $(10 \mu \mathrm{g})$, trimethoprim/sulfamethoxazole $(25 \mu \mathrm{g})$, norfloxacin $(10 \mu \mathrm{g})$, nalidxic $(30 \mu \mathrm{g})$, ofloxacin $(5 \mu \mathrm{g})$ ciprofloxacin $(5 \mu \mathrm{g})$ and levofloxacin $(5 \mu \mathrm{g})$ (Oxoid, UK). All isolates showed intermediate susceptibility were considered as resistant strains.

ESBL detection was detected by the use of a double-disk synergy test, and a test was considered positive if any distortion or zone increase towards the disc of amoxicillin-clavulanate was detected as reported by Paterson and Bonomo [11].

The cefoxitin Hodge test was used to screen strains producing Amp C $\beta$-lactamase and the test was interpreted positive in case of the presence of clear growth of the control strain (ATCC E. coli 25922) along with the test isolate within the $22 \mathrm{~mm}$ inhibition zone after overnight Incubation at $37^{\circ} \mathrm{C}$ [12].

\section{Multiplex PCR technique}

Quick DNA extraction was done by a boiling technique that consists of a heating at $100^{\circ} \mathrm{C}$ of one colony in a volume of $100 \mu \mathrm{L}$ of distilled water for 5 minutes then centrifugation of the cell suspension.

Multiplex PCR amplification of qnrA, qnrB, and qnrS was carried out according to Robicseket al 2006. Primer sets used are listed in table (1) [13]. All primers were added to the template DNA and PCR master mix (Fermentas). The cycling conditions used were $94^{\circ} \mathrm{C}$ for $45 \mathrm{~s}$ (denaturation), $53^{\circ} \mathrm{C}$ for $45 \mathrm{~s}$ (annealing), and $72^{\circ} \mathrm{C}$ for $60 \mathrm{~s}$ (extension), which was repeated for 32 cycles. Another multiplex of PCR was held for amplification of $\operatorname{aac}\left(6^{\prime}\right)-I b$ and qep with sequence of primers [14] mentioned as presented in Table (1). PCR conditions were $94^{\circ} \mathrm{C}$ for $45 \mathrm{~s}, 55^{\circ} \mathrm{C}$ for $45 \mathrm{~s}$, and $72^{\circ} \mathrm{C}$ for $45 \mathrm{~s}$ for 34 cycles. All positive PCR products for aac $\left(6^{\prime}\right)-1 b$ were subsequently analyzed by digestion with $\mathrm{Bts} C \mathrm{Cl}$ (Thermo Fisher

Table 1. Primers for amplification of PMQR molecular determinants

\begin{tabular}{|c|c|c|c|}
\hline PMQR gene & $\begin{array}{c}\text { sequence of primer } \\
5^{\prime} \text { to } 3^{\prime}\end{array}$ & $\begin{array}{c}\text { size of } \\
\text { amplicon } \\
\text { (bp) }\end{array}$ & reference \\
\hline qnrA & $\begin{array}{l}\text { FW5'-ATTTCTCACGCCAGGATTTG-3' } \\
\text { DW5'-GATCGGCAAAGGTTAGGTCA-3' }\end{array}$ & 516 & 13 \\
\hline$q n r B$ & $\begin{array}{l}\text { FW5-'GATCGTGAAAGCCAGAAAGG-3' } \\
\text { DW5'-ACGATGCCTGGTAGTTGTCC-3' }\end{array}$ & 469 & 13 \\
\hline qnrs & $\begin{array}{l}\text { FW5'-ACGACATTCGTCAACTGCAA-3' } \\
\text { DW5-TAAATTGGCACCCTGTAGGC-3' }\end{array}$ & 417 & 13 \\
\hline $\operatorname{aac}\left(6^{\prime}\right)-1 b$ & $\begin{array}{l}\text { FW5-TTGCGATGCTCTATGAGTGGCTA-3' } \\
\text { DW5'-CTCGAATGCCTGGCGTGTTT-3' }\end{array}$ & 482 & 14 \\
\hline qep & $\begin{array}{l}\text { FW5'- AACTGCTTGAGCCCGTAGAT -3' } \\
\text { DW 5- GTCTACGCCATGGACCTCAC-3' }\end{array}$ & 596 & 14 \\
\hline
\end{tabular}


Scientific $\left.{ }^{\mathrm{TM}}\right)$ to detect $\operatorname{aac}\left(6^{\prime}\right)-I b-c r$, that is deficient in the $B t s C l$ restriction site found in the wild-type gene. The wild-type aac(6')-Ib PCR gave 210bp and 272-bp fragments after restriction [15]. Amplification products were identified by their sizes in 2\% ethidium bromide-stained agarose gels using 50bp DNA as control marker.

\section{Statistical Analysis}

Chi-square analysis was done to verify correlation between PMQR determinants and ESBI and Amp C producers. All statistical analyses were performed using Statistical Package for Social Science program (SPSS version 15.0 for windows, Chicago, IL). P $\leq$ 0.05 was considered statistically significant.

\section{Results}

A total of 111 S. marcescens isolates were isolated from various clinical specimens. These isolates were obtained from the respiratory tract $(69.6 \%)$, wounds (8.7\%), blood (5.8\%), urine $(2.9 \%)$, body fluids (3.9\%), and the rest (9.1\%) from other body sites. Resistance to one or more of the used quinolone was detected in $51 / 111(45.9 \%)$ of S. marcescens isolates. Among the isolated S. marcescens, 13 (11.7) isolates showed enhancement of the inhibitory zones of ceftazadime by clavulanic acid, signifying the existence of ESBL activity, while 5 had a positive results for amp C (4.5\%) production using the cefoxitin Hodge test. No isolates showed combined ESBL and Amp C production. S. marcescens harbored qnr determinants in 14 isolates (12.6\%). The $q n r$ types, qnrA and qnr $B$ genes were detected in 3 and 10 isolates, respectively, whereas one isolate co-expressed aac(6')-Ib-cr and qnrA. None of the isolates expressed qep gene. All detected PMQR gene determinants were quinolone resistant (14/ $51 ; 27.5 \%)$. Among ESBL producers, 3 and 5 isolates harbored qnrA and $q n r B$ genes, respectively. While one isolate co- harbored aac $\left(6^{\prime}\right)-I b-c r$ and qnrA and was Amp C producers (1/5; 20\%). The occurrence of PMQR genes was more frequent among ESBL S. marcescens $(8 / 13 ; 61.5 \%)$ than in non-ESBL producers $(6 / 98 ; 6.1 \%)(p<0.05)$.

Table 2. Distribution of PMQR among S. marcescens ESBL and non ESBL producers

\begin{tabular}{|c|c|c|c|}
\hline \multirow[t]{2}{*}{ PMQR genes } & $\begin{array}{c}\text { N. (\%) } \\
\text { S. marcescens ESBL producers } \\
\text { non Ampc producers }\end{array}$ & $\begin{array}{l}\text { N. (\%) } \\
\text { S. marcescens non ESBL } \\
\text { producers }\end{array}$ & $\begin{array}{c}\text { Total } \\
\text { N. (\%) S. marcescens }\end{array}$ \\
\hline & $13(11.7)$ & $98(88.3)$ & $111(100)$ \\
\hline qnrA & $3(37.5)$ & $0(0)$ & $3(2.7)$ \\
\hline qnr B & $5(62.5)$ & $5(5.1)$ & 10(9) \\
\hline qnrs & $0(0)$ & $0(0)$ & $0(0)$ \\
\hline$q n r A+a a c\left(6^{\prime}\right)-I b-c r$ & $0(0)$ & $1(1)$ & $1(0.9)$ \\
\hline qep & $0(0)$ & $0(0)$ & $0(0)$ \\
\hline Total PMQR & $8(61.5)$ & $6(6.1)$ & $14(12.6)$ \\
\hline
\end{tabular}


Table 3. Distribution of PMQR among S. marcescens Amp C and non Amp C producers

\begin{tabular}{|c|c|c|c|}
\hline & $\begin{array}{l}\text { S. marcescens } \\
\text { Amp C producers }\end{array}$ & $\begin{array}{l}\text { S.marcescens non Amp C } \\
\text { producers }\end{array}$ & S. marcescens \\
\hline & $\frac{\text { N. }(\%)}{5(4.5)}$ & $\frac{\text { N. }(\%)}{106(95.5)}$ & $\frac{\text { N. }(\%)}{111(100)}$ \\
\hline qnrA & $0(0)$ & $3(2.8)$ & $3(2.7)$ \\
\hline qnr B & $0(0)$ & $10(9.4)$ & $10(9)$ \\
\hline qnrs & $0(0)$ & $0(0)$ & $0(0)$ \\
\hline$q n r A+\operatorname{aac}\left(6^{\prime}\right)-1 b-c r$ & $1(20)$ & $0(0)$ & $1(0.9)$ \\
\hline qep & $0(0)$ & $0(0)$ & $0(0)$ \\
\hline Total no. (\%) & $1(20)$ & $13(12.3)$ & $14(12.6)$ \\
\hline
\end{tabular}

Table 4. Frequency of Quinolone resistance and PMQR determinants along with their types among isolated Serratia marcescens over 6 years.

\begin{tabular}{|c|c|c|c|c|}
\hline year & $\begin{array}{l}\text { N. (\%) Quinolone -R } \\
\text { S.marcescens }\end{array}$ & $\begin{array}{l}\text { N. (\%) } \\
\text { PMQR producing } \\
\text { S. marcescens }\end{array}$ & $\begin{array}{c}\text { N. (\%) } \\
\text { PMQR determinant } \\
\text { S. marcescens }\end{array}$ & $\begin{array}{c}\text { Total } \mathrm{n} .(\%) \\
\text { S.marcescens / year }\end{array}$ \\
\hline $2008-2009$ & $2(18.2)$ & Null & - & $11(100)$ \\
\hline $2009-2010$ & $5(22.7)$ & Null & - & $22(100)$ \\
\hline $2010-2011$ & 5 (31.3) & $1(6.3)$ & $q n r B$ & $16(100)$ \\
\hline $2011-2012$ & $11(45.8)$ & $3(12.5)$ & $2 q n r B, 1$ qnr $A$ & $24(100)$ \\
\hline 2012- 2013 & $13(65 \%)$ & $4(20)$ & 4 qnr B & $20(100)$ \\
\hline $2013-2014$ & $15(83.3)$ & $6(33.3)$ & $\begin{array}{c}3 \text { qnr B, } 2 \text { qnr } A, 1 \\
\text { combined qnr } A \text { and } \\
\text { aac }\left(6^{\prime}\right)-l b-c r\end{array}$ & $18(100 \%)$ \\
\hline
\end{tabular}


(Table 2) No statistical significance was observed regarding $\mathrm{PMQR}$ among $S$. marcescens Amp C (1/ 5; 20\%) and non Amp C producers (13/ 106, $12.3 \%)(p>0.05)$. (Table 3 ) Over the six years study period the overall frequency of PMQR gene determinants together with quinolone resistance have progressively increased by time. (Table 4).

\section{Discussion}

This study has detected quinolone resistance at a rate of $45.9 \%$, whereas a study by Park et al. in USA [16], found a higher rate of resistance to quinolones (66.3\%), and the study of Yang et al. in China [17], reported much lower results (10.3\%). The overall frequency of PMQR genes among the $S$. marcescens isolates in our study was $12.6 \%$ which is similar to other recent study that carried in China [3], while the study of Park et al. [16], on the contrary has showed much lower frequency (2.4\%).

The present study demonstrates that the quinolone resistance was increased over time together with a growing shift to PMQR molecular determinants. This increase may be attributed to performance and enhancement of selection pressure of resistant mutants especially with extensive use of quinolones over the study period. In addition, further increase in the magnitude of the problem could be supported by the hypothesis that PMQR encourage emergence of QRDR mutations in gyrA and parC associated with quinolone resistance $[14,17]$.

This study shows that $q n r B$ is the most dominant (71.4\%) among PMQR genes, ant it is similar to many other studies over the world [6,7,18-21]. Moreover, this gene was the most common among ESBL producers signifying the relation between this gene and other resistance genes as observed by other researchers [22-25]. In contrast to the current results, the data reported by Yang et al. [3], found that the $\operatorname{aac}\left(6^{\prime}\right)-I b-c r$ gene was the most prevalent among S. marcescens ESBL producers. Additionally, Robicsek et al. [7], found this gene to be the most common in E. coli and the reason of this finding could not be explained. However, a different geographic distribution could be suggested as a cause for this variation. It is noted that aac $\left(6^{\prime}\right)-I b-c r$ and qnrA were co-expressed in one of our isolates, This finding support other reported results where some plasmids can carry both aac $\left(6^{\prime}\right)-I b-c r$ and $q n r A$ [14]. This association confers the superior level of resistance to quinolones than do each gene by itself, although other studies found no relation between qnr genes and aac $\left(6^{\prime}\right)-1 b-c r$ gene $[7,26]$.

The frequency of the PMQR determinants in ESBL producing S. marcescens isolated from hospitals in this study was $61.5 \%$., while a study done in Korea has detected only $4.8 \%$ as qnr-positive among ESBL producing S. marcescens strains [16]. However, high incidence (71.4\%) has also been found in China [3]. A low incidence of qnr genes was detected among ESBL producing isolates of E. coli and Klebsiella spp. in France and Canada(1.6\% and 1\%, respectively), whereas high frequency of the qnr genes was reported in Egypt (26.6\%) among ESBL producing E.coli [26], and in Spain, this prevalence was found among ESBL producing E.coli and Klebsiella at 5\% and $8 \%$, respectively [27].

Although our study has not detected any statistically significant results regarding the presence of PMQR determinants in association with pAmpCs (20\%), it is still important to report that PMQR genes are frequently linked to ESBLs and/or pAmpCs and they can be transferred by conjugation [3].

The high frequency of PMQR among ESBL and Amp C producers in this study could be attributed to the genetic linkage and horizontal transfer of these resistance genes on plasmids [4].

In conclusion, quinolones are important drugs used in the treatment of infections caused by $S$. marcescens. Therefore, the increased frequency of 
PMQRs among this organism over 6-year signifies a real therapeutic problem. Moreover, the close association between PMQR, ESBLs and Amp C genes in this organism would cause failure of treatment. This study recommends continuous surveillance to detect and molecular characterization of resistant bacteria isolates in hospitalized patients.

\section{Acknowledgment}

The authors would like to thank MDICU for supplying Gram negative bacteria to be further identified as Serratia marcescens.

\section{References}

1. Kumar A, Worobec EA.. Fluoroquinolone resistance of Serratia marcescens: involvement of a proton gradient-dependent efflux pump. J Antimicrob Chemother 2002; 50:593-596.

2. Michael A K, Daniel J D, and James J C. How antibiotics kill bacteria: from targets to networks. Nature Reviews Microbiology 2010; $8: 423-435$.

3. Yang HF, Cheng J, Hu LF, Ye Y, Li JB. Plasmid-Mediated Quinolone Resistance in Extended-Spectrum- $\beta$-Lactamase. and Amp C $\beta$-Lactamase-Producing Serratia marcescens in China. Antimicrob Agents Chemother 2012; 56: 4529-4531

4. Jeong HS, Bae IK, Shin JH, Jung HJ, Kim SH, Lee JY, Oh SH, Kim HR, Chang CL, Kho WG, Lee JN.. Prevalence of plasmidmediated quinolone resistance and its association with extended-spectrum beta-lactamase and Amp C beta-lactamase in Enterobacteriaceae. Korean J Lab Med 2011; 31:257-264.

5. Robicsek A, Jacoby GA, Hooper DC.. The worldwide emergence of plasmid-mediated quinolone resistance. Lancet Infect. 2006; 6: 629-40.

6. Poirel L, Leviandier C, Nordmann P.. Prevalence and genetic analysis of plasmid-mediated quinolone resistance determinants QnrA and QnrS in Enterobacteriaceae isolates from a French university hospital. Antimicrob Agents Chemother 2006; 50: 3992-7.

7. Robicsek A, Strahilevitz J, Jacoby GA, Macielag M, Abbanat D, Park CH, Bush K, Hooper DC.. Fluoroquinolone-modifying enzyme: a new adaptation of a common aminoglycoside acetyltransferase. Nat Med 2006; 12: 83-8.

8. Yamane K, Wachino J, Suzuki S, Kimura K, Shibata N, Kato H, Shibayama K, Konda T, Arakawa Y. New plasmid-mediated fluoroquinolone efflux pump, QepA, found in an Escherichia coli clinical isolate. Antimicrob Agents Chemother 2007.; 51: 3354-60.

9. Hejazi A, Falkiner FR. 1997. Serratia marcescens J. Med. Microbiol. 46: 903-912

10. Clinical Laboratory Standards Institute. Performance standards for antimicrobial disk susceptibility tests. 2012; Approved standard, 10th ed. CLSI document M 02-A11. CLSI, Wayne, PA, USA.

11. Paterson DL, Bonomo RA. Extended spectrum $\beta$-lactamases: a clinical update. Clin Microbiol Rev 2005; 18:657-86.

12. Black JA, Moland ES, Thomson KS. AmpC Disk Test for detection of plasmid-mediated AmpC $\beta$-lactamase in Enterobacteriacae lacking chromosomal AmpC $\beta$-lactamase. J Clin Microbiol 2005; 43:3110-13.

13. Robicsek A, Strahilevitz J, Sahm DF, Jacoby GA, Hooper DC. qnr prevalence in ceftazidime-resistant Enterobacteriaceae isolates from the United States. Antimicrob. Agents Chemother 2006; 50:2872-2874.

14. Kim HB, Park CH, Kim CJ, Kim EC, Jacoby GA, Hooper DC. Prevalence of Plasmid-Mediated Quinolone Resistance Determinants over a 9-Year Period. Antimicrob Agents Chemother 2009; 53 :639-45.

15. Park, C. H., A. Robicsek, G. A. Jacoby, D. Sahm, and D. C. Hooper. Prevalence in the United States of aac $\left(6^{\prime}\right)-I b-c r$ encoding a ciprofloxacin-modifying enzyme. Antimicrob. Agents Chemother 2006; 50:3953-3955.

16. Park YJ, Yu JK, Lee S, Oh EJ, Woo GJ. Prevalence and diversity of qur Alleles in AmpC-producing Enterobacter cloacae, Enterobacter aerogenes, Citrobacter freundii and Serratia marcescens: a multicentre study from Korea. J Antimicrob Chemother 2007 ; 60: 868-871.

17. Yang $H$, Chen $H$, Yang Q, Chen $M$, Wang $H$. High Prevalence of Plasmid-Mediated Quinolone Resistance Genes qnr and aac $\left(6^{\prime}\right)-\mathrm{lb}-\mathrm{cr}$ in Clinical Isolates of Enterobacteriaceae from Nine Teaching Hospitals in China. Antimicrob Agents Chemother 2008;52: 4268-4273.

18. Minarini LA, Poirel L, Cattoir V, Darini AL, Nordmann P. Plasmid-mediated quinolone resistance determinants among enterobacterial isolates from outpatients in Brazil. J Antimicrob Chemother 2008; 62:474-478.

19. Strahilevitz J, Engelstein D, Adler A, Temper V, Moses AE, Block $C$, Robicsek A. Changes in qnr prevalence and fluoroquinolone resistance in clinical isolates of Klebsiella pneumoniae and Enterobacter spp. collected from 1990 to 2005. Antimicrob Agents Chemother 2007; 51:3001-3003.

20. Wu JJ, Ko WC, Tsai SH, Yan JJ. Prevalence of plasmid-mediated quinolone resistance determinants QnrA, QnrB, and QnrS among clinical isolates of Enterobacter cloacae in a Taiwanese hospital. Antimicrob Agents Chemother 2007; 51:1223-1227.

21. Wu JJ, Ko WC, Wu HM, Yan JJ. Prevalence of Qnr determinants among bloodstream isolates of Escherichia coli and Klebsiella pneumoniae in a Taiwanese hospital, 1999-2005. J Antimicrob Chemother 2008; 61:1234-1239. 
22. Corkill JE, Anson JJ, Hart CA. High prevalence of the plasmidmediated quinolone resistance determinant qnrA in multidrugresistant Enterobacteriaceae from blood cultures in Liverpool, United Kingdom. J Antimicrob Chemother 2005; 56:1115-1117.

23. Jacoby GA, Walsh KE, Mills DM, Walker VJ, Oh H, Robicsek A, Hooper DC. qnrB, another plasmid-mediated gene for quinolone resistance. Antimicrob Agents Chemother 2006; 50:1178-1182.

24. Nordmann P, Poirel L. Emergence of plasmid-mediated resistance to quinolones in Enterobacteriaceae. J Antimicrob Chemother 2005; 56:463-469

25. Wang M, Tran JH, Jacoby GA, Zhang Y, Wang F, Hooper DC. Plasmid-mediated quinolone resistance in clinical isolates of Escherichia coli from Shanghai, China. Antimicrob Agents Chemother 2003; 47:2242-2248

26. Hassan WM, Hashim A, Domany R. Plasmid mediated quinolone resistance determinants $q n r$, aac $\left(6^{\prime}\right)-\mathrm{lb}-\mathrm{cr}$, and qep in ESBLproducing Escherichia coli clinical isolates from Egypt. Ind J Microbial 2012 ; 30: 442-447.

27. Lavilla S, González-López JJ, Sabaté M, García-Fernández A, Larrosa MN, Bartolomé RM, Carattoli A, Prats G. Prevalence of qur genes among extended-spectrum beta-lactamaseproducing enterobacterial isolates in Barcelona, Spain. J Antimicrob Chemother 2008; 61:291-5.

28. Jiang Y, Zhou Z, Qian Y, Wei Z, Yu Y, Hu S, Li L. Plasmid-mediated quinolone resistance determinants qnrAnd aac $\left(6^{\prime}\right)-\mathrm{Ib}-\mathrm{Cr}$ in extended-spectrum beta-lactamase-producing Escherichia coli and Klebsiella pneumoniae in China. J Antimicrob Chemother 2008;61:1003-6.

\section{Comment on this article:}

\section{(f) (B) in $8+S$. $P$}

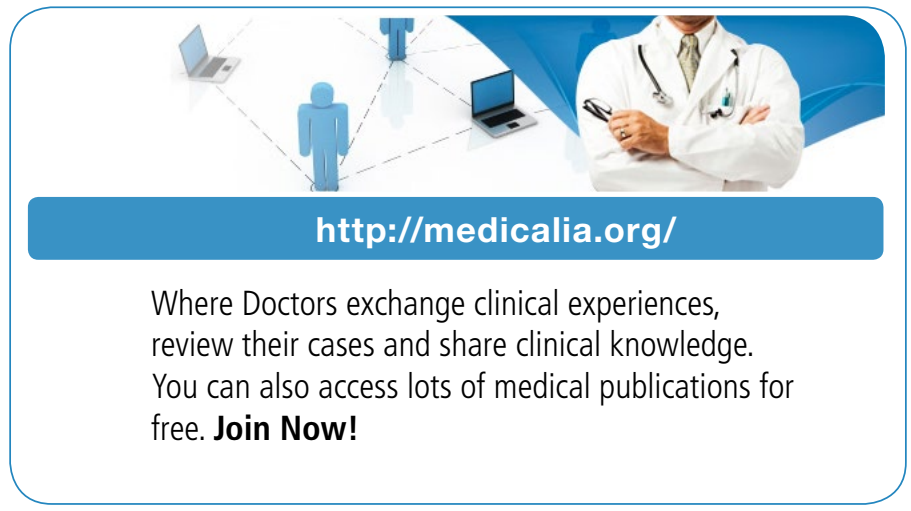

\section{Publish with iMedPub}

http://www.imed.pub

The Journal is an open access peer-reviewed journal that publishes scientific papers about all aspects of antimicrobials. The journal will publish original research articles, reviews, brief reports and case reports dealing with basic and clinical antibacterial agents, antiviral, antiprotozoals, antituberculuous, antifungal and antihelminthes agents.

All manuscripts must be prepared in English, and are subject to a rigorous and fair peer-review process. Accepted papers will immediately appear online.

The journal aims to advance the knowledge, attitude and the research of chemotherapy in the Arabic world in cooperation with international, national scientific and public societies as well as research centers with similar aims and objectives. 